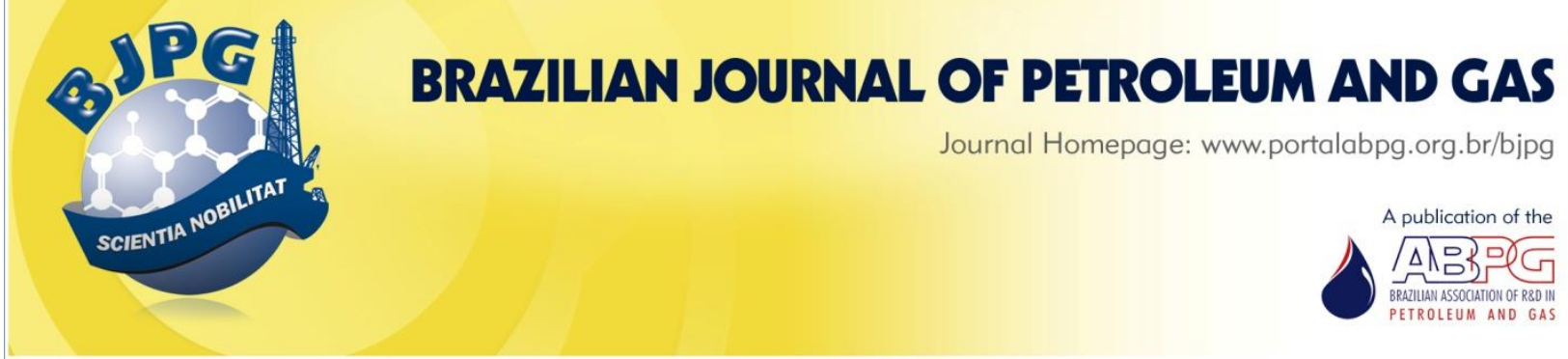

\title{
OIL SLUDGE TREATMENT BY SOLAR TIO 2 -PHOTOCATALYSIS TO REMOVE POLYCYCLIC AROMATIC HYDROCARBONS (PAH)
}

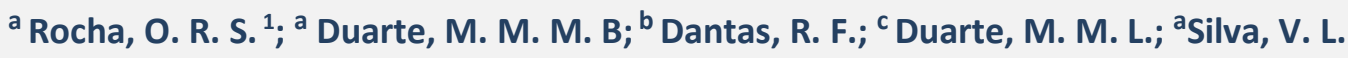 \\ ${ }^{a}$ Federal University of Pernambuco - UFPE, Recife, PE, Brazil \\ ${ }^{b}$ School of Technology, University of Campinas, Campinas, SP, Brazil \\ c Federal University of Rio Grande do Norte - UFRN, Technology Center- CT, Natal, RN, Brazil
}

\begin{abstract}
The objective of this study is to explore the treatment of oil sludge by heterogeneous photocatalysis $\left(\mathrm{H}_{2} \mathrm{O}_{2} / \mathrm{TiO}_{2} / \mathrm{UV}\right)$ using solar radiation. Comparisons of total organic carbon (TOC) and polycyclic aromatic hydrocarbons (PAH) removal from the sludge, before and after photodegradation, proved the efficiency of the treatment. The EPA 3540 - Soxhlet extraction method was used to determine PAH. The quantification of PAH was performed by the EPA 8270 - semi-volatile organic components identification method- using chromatography/mass spectrometry (GC/MS). The methodology for determining the TOC was the WalkeyBlack modified method. The treatment method removed $90.7 \%$ of TOC after 144 hours of exposure to solar radiation, eliminating $100 \%$ of $\mathrm{PAH}$ after 96 hours using $5 \mathrm{mg}$ of $\mathrm{TiO}_{2}$ and $0.8 \mathrm{~mol}^{-\mathrm{L}^{-1}}$ of hydrogen peroxide.
\end{abstract}

\section{KEYWORDS}

heterogeneous photocatalysis; PAH; oil sludge; solar radiation

\footnotetext{
${ }^{1}$ To whom all correspondence should be addressed.

Address: Federal University of Pernambuco, Av.Arthur de Sa, S/N, Cidade Universitária - Recife / PE / Brazil Zip Code: 50740-521|Telephone: (55) 81 2126-7322 |Fax: (55) 81 2126-7278 |e-mail: otidene@eq.ufrn.br doi:10.5419/bjpg2014-0008
} 


\section{INTRODUCTION}

The soils or sediments contaminated with oil are mixtures composed by numerous chemical species, with diverse physicochemical properties, which present an extensive range of toxicity to organisms (Tang et al., 2011). Among the harmful chemical species present in this type of waste, the polycyclic aromatic hydrocarbons (PAH) are a group of chemicals known for being genotoxic. The relevance of studying PAH in light of environmental regulations is due to their potential hazardous effects on public health (Yang et al., 1991; Tarantini et al., 2011).

The main emissions of PAH result from anthropogenic sources such as the burning fossil fuels, atmospheric carriage by adsorption by soot or particulate matter, drag and deposit of the abrasion products from asphalt and tires, vehicle emissions, oil spills, and byproducts containing complex mixtures of PAH (Kibble \& Harrison, 2005; Martins et al., 2007; Audebert et al., 2012). The composition and complexity of $\mathrm{PAH}$ mixtures generated through these different processes, which depend on the emission sources (USEPA, 1995), justify the growing interest in researching them (Faria \& Rosa, 2004; Reynaud \& Deschaux, 2006; Alomirah et al., 2011).

PAH have a tendency to persist in the environment and natural resources, such as sediments, soil, water, and air, resulting in a widespread distribution; in water, because of its hydrophobic characteristic and low solubility, being also able to pollute sediments (Ferrarese, 2008). The interaction of these pollutants in the soil occurs by attractive forces such as dipole-dipole, induced dipole, and hydrogen bonds (Pignatello \& Xing, 1996).

Oil pollution in soils can be produced by accidental spills and the leakage in underground storage tanks (Khamehchiyan et al., 2007).

The efficiency of bio-remediation methods is affected by a number of physical, chemical, and environmental issues, in example, soil porestructure, aeration, toxic oil constituents, and nutrient availability. Further, the chemical oxidation processes may offer a better solution for partial or even complete contaminant degradation (Hamed et al., 1991).
The majority of the methods devoted to oil sludge treatment are based on biodegradation. However, biodegradation cannot remove some of the toxic or low biodegradable contaminants. Literature addressing the chemical and/or physical transformation of oil sludge is sparse. Some methods used in the treatment of oil sludge, which have been cited are pyrolysis (Liu et al., 2009), microwave (Jiang et al., 2012), thermal-oxidative (Shie et al., 2004), flotation (Sokolov et al., 1979), and $\mathrm{UV}-\mathrm{TiO}_{2}$ (Da Rocha et al., 2010). These treatments are effective in removing recalcitrant organic matter and decreasing toxicity. The costs, however, remain as the main problem in chemical treatment, especially those based on oxidative methods. In our research, we investigate the use of solar radiation in an attempt to reduce the overall cost of oxidative treatments.

Conventional oxidation processes use oxygen as the oxidant, ozone, chlorine, sodium hypochlorite, chlorine dioxide, potassium permanganate, and hydrogen peroxide. However, some of these processes are resistant to the direct action of conventional oxidizing agents. In these cases, it is necessary to use advanced oxidation processes, which are methods based on the formation of hydroxyl radicals $(\mathrm{HO} \bullet)$, which have an increased oxidation potential and are capable of reacting with practically all organic compounds' classes (Béltran et al., 1997; Higarashi et al., 2000).

Regardless of the various reaction systems, Advanced Oxidation Processes (AOP) are characterized by the same chemical process, which is a hydroxyl radical production $(\mathrm{HO} \bullet)$. Its versatility is due to their ability to produce hydroxyl radicals by different means, depending on specific requirements of each treatment (Amiri et al., 1997; Fernàndez-Alba et al., 2002).

Treatment processes using AOP are considered as promising methods for industrial waste remediation, as well as cleaning up contaminated soils and wastewaters containing nonbiodegradable organic pollutants (Muneer et al., 1997; Chen \& Ray, 2001; Bandala et al., 2008; Da Rocha et al., 2010; Dantas et al., 2010). Fenton's reaction has been used in the chemical remediation of contaminated soil (Mater et al., 2007; Ndjou'ou \& Cassidy, 2006). However, according to Sirguey et al. (2008), the use of 
Fenton reaction in the treatment of petroleum contaminated soil may cause the inhibition of plant growth due the reduction in the $\mathrm{pH}$ of the soil. To attenuate this possible problem, one can use the stabilization with lime.

Among the various AOP, the heterogeneous photocatalysis has emerged as a suitable alternative to treat a large quantity of organic pollutants (Esplugas et al., 2002). Heterogeneous photocatalysis involves the photocatalyst irradiation of a semiconductor (inorganic). $\mathrm{TiO}_{2}$ is used widely in this process due to its efficiency, stability, and solubility in water (Percherancier et al., 1995). The objective of this work is to study the degradation of total organic carbon (TOC) and PAH present in oil sludge using heterogeneous photocatalysis $\left(\mathrm{H}_{2} \mathrm{O}_{2} / \mathrm{TiO}_{2} / \mathrm{UV}\right)$.

\section{MATERIALS AND METHODS}

\subsection{0il sludge characterization}

The samples used in this investigation were withdrawn from oil storage tanks located in the State of Rio Grande do Norte, Brazil (Petrobras S. A., Brazil). First, the samples were examined for metals and $\mathrm{pH}$. Flame Atomic Absorption Spectrometry was used to analyze metals, including iron (Varian AA240FS), using standard methodology (Lenore et al., 1998).

Measurements of PAH and TOC were performed as described in the following sections.

\subsection{PAH analysis}

The PAH extraction method used the EPA protocol 3540, utilizing Soxhlet extraction and 300 $\mathrm{mg}$ of oil sludge (before or after treatment). The $\mathrm{PAH}$ quantification was performed employing gas chromatography following the EPA 8270 method. The method was replicated using a GC/MS (Shimadsu models GC-17A and QP5050A, respectively). It used was a DB-5 MS capillary column (length $=30 \mathrm{~m}$, inner diameter $=0.25$, and film thickness $=0.25 \mu \mathrm{m}$ ) with an injector temperature of $280^{\circ} \mathrm{C}$ in split less mode. Other chromatographic conditions were: initial oven temperature of $80-120^{\circ} \mathrm{C}$, with a ramp of $20^{\circ} \mathrm{Cmin}^{-}$ ${ }^{1}$, and $120-285^{\circ} \mathrm{C}$, with $2.8^{\circ} \mathrm{C} \mathrm{min}^{-1}$. The detection limit was $0.25 \mathrm{mg} \mathrm{kg}^{-1}$.

\subsection{Total Organic Carbon (TOC) analysis}

The methodology employed to determine the TOC was the Walkey-Black modified method, described by Embrapa (Embrapa, 1997).

The methodology is based on the oxidation of the present organic carbon by potassium dichromate $\left(\mathrm{K}_{2} \mathrm{Cr}_{2} \mathrm{O}_{7}, 4 \mathrm{~N}\right)$ in acidic medium, thus, forming carbon dioxide and water.

\subsection{Photocatalytic experiments}

To perform the experiments, $300 \mathrm{mg}$ of samples were exposed to solar radiation in Petri dishes with a surface area of $63.6 \mathrm{~cm}^{2}$. To obtain the best experimental conditions, a $2^{3}$ factorial design was used with radiation time (96 and 144 hours), $\mathrm{H}_{2} \mathrm{O}_{2}$ (30\% w/w, Merck, Brazil) concentration (0.4 and $0.8 \mathrm{~mol} \mathrm{~L}^{-1}$ ), titanium dioxide (Degussa P25) mass (5 and $6 \mathrm{mg}$ ) as the variables. The $\mathrm{TiO}_{2} \mathrm{P} 25$ presented a specific surface area (BET) of $50 \pm 15 \mathrm{~m}^{2} \mathrm{~g}^{-1}$, and an average primary particle size of $21 \mathrm{~nm}$ (EVONIK, Germany). The TOC removal was the response for this experimental plan. The hydrogen peroxide concentration used refers to a volume of $21 \mathrm{~mL}$, added every 24 hours. The experiments were exposed to solar radiation for 12 hours and, then, another 12 hours without radiation. To verify the efficiency of each individual experiment, the comparison between TOC measurements before and after photodegradation was carried out.

The experiments were performed in duplicate, yielding a pure error of $0.5 \%$. Experiments were conducted during the month of October, in Recife, Brazil ( $8^{\circ} 04^{\prime} 03^{\prime \prime} \mathrm{S} ; 34^{\circ} 55^{\prime} 00^{\prime \prime} \mathrm{W}$ ), at the same time every day in order to avoid incidental radiation variance. The average solar radiation was approximately $17 \mathrm{~mJ} \mathrm{~m}^{-2} \mathrm{~s}^{-1}$ in the wavelength range of $380-780 \mathrm{~nm}$.

\section{RESULTS AND DISCUSSION}

\subsection{Characterization of sludge}

By quantifying the metals it is possible to discover the inorganic portion of the sludge that, inevitably, will be left over after organic degradation. From Table 1, one can see that, among the metals analyzed, only cadmium was not detected. Iron stood out significantly in terms of 
Table 1. Quantities of metals present in the oil sludge.

\begin{tabular}{cccc}
\hline Metal & $\mathrm{mg} \mathrm{kg}^{-1}$ & Metal & $\mathrm{mg} \mathrm{kg}^{-1}$ \\
\hline Cadmium & - & Iron & 3500 \\
Lead & 565 & Manganese & 542 \\
Cobalt & 100 & Nickel & 125 \\
Copper & 214 & Zinc & 769 \\
Chrome & 119 & & \\
\hline
\end{tabular}

quantity ( $34.5 \mathrm{mg} \mathrm{kg}^{-1}$ ), which is justified because of the specific composition of the material (oil sludge) and the manner in which it is stored. The material used in this study was taken from oil tanks, and possible corrosion in these tanks may explain the great amount of iron found, if compared to other metals.

The sample showed a $\mathrm{pH}$ around 5, and had an appearance similar to a very viscous black grease, presenting an oil-like strong odor.

The PAH present in the untreated oil sludge are shown in Table 2.

The literature describes PAH soil levels in environmental samples in in the range of $0.8 \mathrm{mg} \mathrm{kg}$ 1 to $100 \mathrm{mg} \mathrm{kg}^{-1}$ (Pereira Netto et al., 2000). Compared to those found in the untreated sludge used in this study $\left(218.22 \mathrm{mg} \mathrm{kg} \mathrm{g}^{-1}\right)$, the high potential for contamination by PAH (polyaromatic hydrocarbons) was confirmed.

\subsection{Removal of total organic carbon}

The TOC analysis of the sample of oil sludge without treatment obtained $547.27 \mathrm{~g}$ of carbon $\mathrm{kg}^{-1}$ initial content in the sample. To corroborate the accuracy of the data, blank tests were performed and no significant removal was achieved by any single element of the photocatalysis, such as solar radiation, hydrogen peroxide, or $\mathrm{TiO}_{2}$ alone. The levels of the variables of this factorial design were determined by the experience acquired during these preliminary tests.

The removal of TOC values obtained in the experimental design varied from $84.7 \%$ to $92.2 \%$.

The experiments used the Statistical Experimental Design program, which treated the
Table 2. PAH identified in untreated sludge.

\begin{tabular}{lcc}
\hline PAH & mg kg $^{-1}$ & $\boldsymbol{\Sigma}$ \\
\hline Naphthalene & 6.34 & \pm 1.54 \\
Acenaphthylene & $<\mathrm{LQ}^{*}$ & - \\
Acenaphthene & 7.99 & \pm 0.34 \\
Fluorene & 21.29 & \pm 0.22 \\
Phenanthrene & 40.90 & \pm 0.68 \\
Anthracene & $<\mathrm{LQ}^{*}$ & - \\
Fluoranthene & 20.68 & \pm 0.50 \\
Pyrene & 23.70 & \pm 0.52 \\
Benzo (a) anthracene & 21.29 & \pm 0.05 \\
Chrysene & 26.07 & \pm 0.63 \\
Benzo (b) fluoranthene & 29.41 & \pm 3.80 \\
Benzo (k) fluoranthene & 4.61 & \pm 1.36 \\
Benzo (a) pyrene & 10.42 & \pm 0.74 \\
Indeno (1,2,3-cd) pyrene & 4.56 & \pm 0.96 \\
Dibenzo (a, h) anthracene & 7.02 & \pm 1.70 \\
Benzo (ghi) perylene & 8.58 & \pm 0.91 \\
\hline Total & 218.22 & \pm 1.54 \\
\hline Where ${ }^{*}$ LQ = quantity less than the quantification \\
limit of 0.83 mg kg ${ }^{-1 .}$ & \multicolumn{2}{l}{}
\end{tabular}

obtained data, and an empirical model capable of predicting the system's efficiency in terms of TOC degradation (\%). By applying the studied variables, Equation 1 was generated:

$$
\begin{aligned}
& \mathrm{D}=89.02+1.1812 \mathrm{X}_{\mathrm{Time}}- \\
& -0.8312 \mathrm{X}_{\mathrm{TiO} 2} \mathrm{X}_{\mathrm{H} 2 \mathrm{O} 2}+0.8563 \mathrm{X}_{\mathrm{H} 2 \mathrm{O} 2} \mathrm{X}_{\mathrm{Time}}+ \\
& +0.8063 \mathrm{X}_{\mathrm{TiO} 2} \mathrm{X}_{\mathrm{H} 2 \mathrm{O} 2} \mathrm{X}_{\mathrm{Time}}
\end{aligned}
$$

With the possibility of making use of a source of clean energy, free of cost, with increased response in the degradation of organic substance present in sludge, the process symbolizes a new alternative to the use of present methods.

The significance of all variables studied, and their interactions, are represented in Figure 1, in the Pareto chart. According to the graphic, the Pareto chart values greater than the $P$ value $(0.05)$ are statistically significant. The estimated absolute effect is shown on the $\mathrm{X}$-axis, while the independent variables and their interactions are on the $\mathrm{Y}$-axis. The effect is calculated from the ratio between the estimated effect and its respective standard deviation.

Figure 1 demonstrates that the effect with the highest statistical significance was the main variable, Time. The effects of interactions $\mathrm{H}_{2} \mathrm{O}_{2} \times$ Time and $\mathrm{TiO}_{2} \times \mathrm{H}_{2} \mathrm{O}_{2}$ were also statistically significant, indicating that the greater the amount 


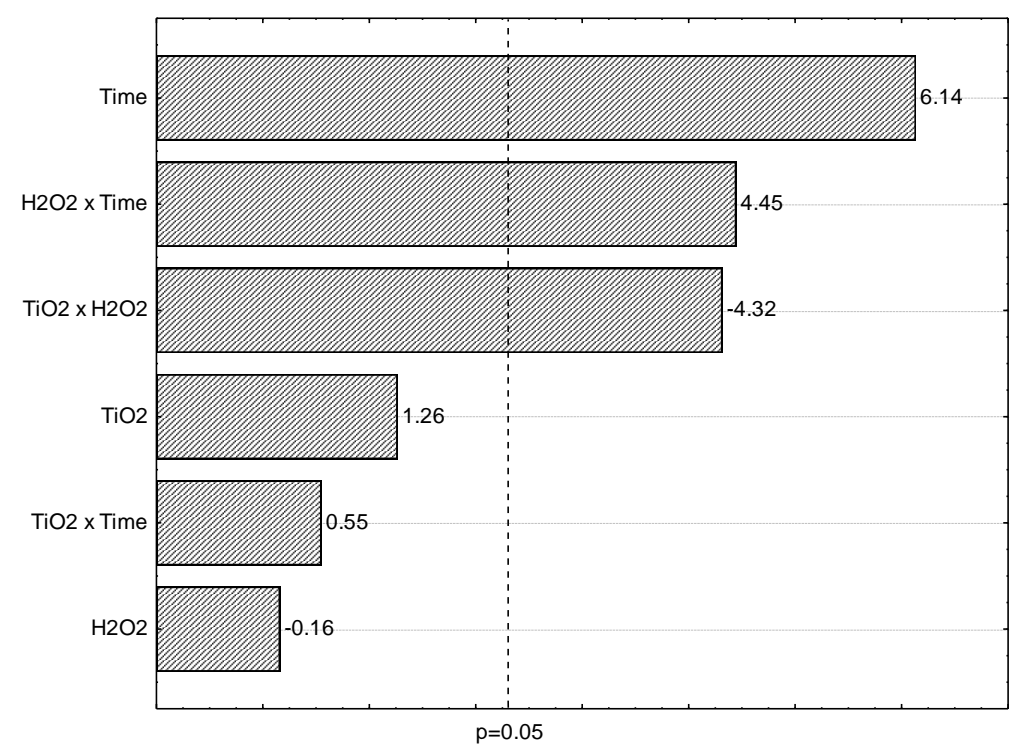

Figure 1. Pareto chart of the variables effect and their interactions.

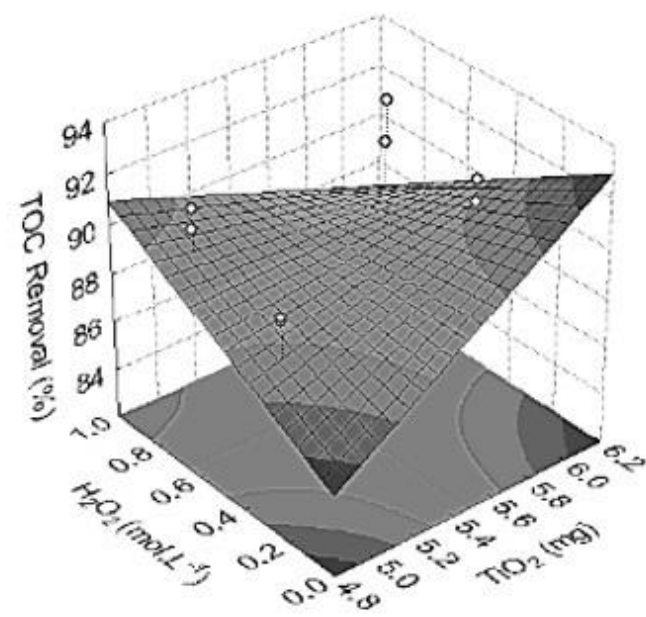

(a)

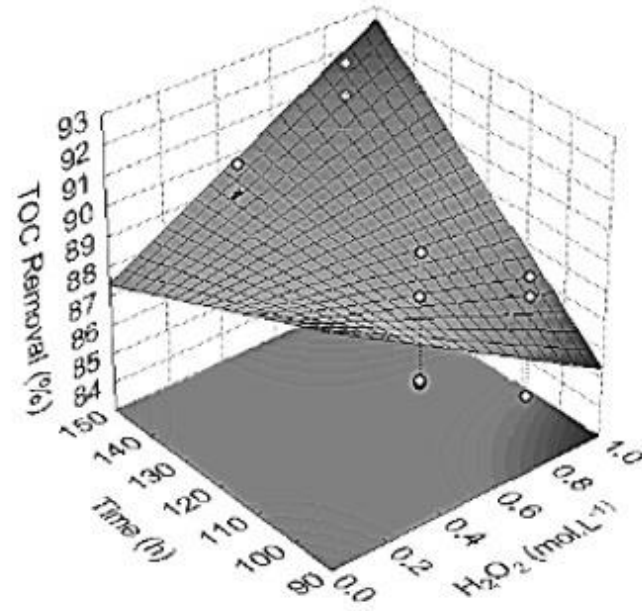

(b)

Figure 2. Response surface graphics for the mineralization of oil sludge sample, using solar radiation. $(\mathrm{a})=\mathrm{H}_{2} \mathrm{O}_{2}$ (mol. ${ }^{-1}$ ) vs. $\mathrm{TiO}_{2}(\mathrm{mg})$, (b) = Time (h) vs. $\mathrm{TiO}_{2}(\mathrm{mg})$.

of time of exposure to solar radiation, the better the result were.

The following steps were to build the response surface graphics using the experimental data and to evaluate their behavior. In this case, the response surface graphics describe the relationship between three variables and one response. The behavior of overall factor influence on oil sludge mineralization is presented in Figure 2.

It can be observed in the first figure that the highest values of degradation of TOC are obtained with a greater amount of $\mathrm{TiO}_{2}$ and a lower concentration of $\mathrm{H}_{2} \mathrm{O}_{2}$, or with a lower amount of $\mathrm{TiO}_{2}$ and greater concentration of $\mathrm{H}_{2} \mathrm{O}_{2}$. Under the conditions studied, these conditions are consistent with the Pareto chart, where the interaction effect $\mathrm{TiO}_{2} \times \mathrm{H}_{2} \mathrm{O}_{2}$ is negative.

In Figure $2 \mathrm{~b}$ one can see that the best results for removal of TOC are obtained by using a longer Time and a higher concentration of $\mathrm{H}_{2} \mathrm{O}_{2}$. 
Table 3. Results in removing the $\mathrm{PAH}(\%)$ using solar radiation.

\begin{tabular}{|c|c|c|c|}
\hline \multirow[t]{2}{*}{ Compound } & \multicolumn{3}{|c|}{ Sun radiation } \\
\hline & $24 \mathrm{~h}$ & $72 \mathrm{~h}$ & $96 \mathrm{~h}$ \\
\hline Naphthalene & 50.00 & 50.04 & 100.00 \\
\hline Fluorene & 37.45 & 37.45 & 100.00 \\
\hline Phenanthrene & 50.69 & 58.51 & 100.00 \\
\hline Fluoranthene & 42.95 & 43.0 & 100.00 \\
\hline Pyrene & 0.00 & 0.00 & 100.00 \\
\hline Benzo (a) anthracene & 51.64 & 56.48 & 100.00 \\
\hline Chrysene & 57.80 & 63.43 & 100.00 \\
\hline Benzo (b) fluoranthene & 3.71 & 100.00 & 100.00 \\
\hline Benzo (k) fluoranthene & 53.97 & 56.53 & 100.00 \\
\hline Benzo (a) pyrene & 46.73 & 100.00 & 100.00 \\
\hline Total & 45.70 & 68.08 & 100.00 \\
\hline
\end{tabular}

\subsection{Removal of PAH}

The previous experimental design was performed to obtain the optimal operating conditions of the treatment. Thus, the best results of TOC removal were achieved using $6 \mathrm{mg}$ of $\mathrm{TiO}_{2}$ and 0.4 mol. $\mathrm{L}^{-1}$ concentration of $\mathrm{H}_{2} \mathrm{O}_{2}$. These experimental conditions were used to perform the irradiation experiments with solar radiation using times of 24,72 , and $96 \mathrm{~h}$. The results are shown in Table 3.

It is observed that, after $96 \mathrm{~h}$, the degradation of HPA was $100 \%$. This result is promising because the radiation source used in this work was the sun, making the process less costly.

\section{CONCLUSIONS}

The results obtained from the present study lead to the following conclusions:

1. Remediation of oil sludge was efficiently achieved in $96 \mathrm{~h}$, under the experimental conditions tested $\left(5 \mathrm{mg} \mathrm{TiO}{ }_{2}\right.$ concentration and $\mathrm{H}_{2} \mathrm{O}_{2} 0.8$ mol.L ${ }^{-1}$ ), obtaining $100 \%$ removal of $\mathrm{PAH}$ using solar radiation.

2. The application of sunlight as the source of UV radiation obtained a success rate of $90.7 \%$ in TOC degradation at $144 \mathrm{~h}$, being cost-effective. However, reaction time should be reduced.

3. The mineralization of organic compounds in the sludge, in response to the TOC degradation with consequent degradation of $\mathrm{PAH}$, indicates the efficiency of the process, and can be considered technically feasible in the remediation of similar environmental matrices.

\section{ACKNOWLEDGEMENTS}

The authors are grateful to the "National Council for Scientific and Technological Development" (CNPq) and the "Foundation of Science of the State of Pernambuco" (FACEPE) for financial support, and to PETROBRAS and DEGUSSA for their invaluable assistance.

\section{REFERENCES}

Alomirah, H.; Al-Zenki, S.; Al-Hooti, S.; Zaghloul, S.; Sawaya, W.; Ahmed, N.; Kannan, K. Concentrations and dietary exposure to polycyclic aromatic hydrocarbons (PAHs) from grilled and smoked foods, Food Control, 22, No. 12, 20282035 (2011).

http://dx.doi.org/10.1016/j.foodcont.2011.05.024

Amiri, A.S.; Bolton, J.R.; Cater, S.R. Ferrioxalatemediated photodegradation of organic pollutants in contaminated water, Water Res., 31, 787-798 (1997).

http://dx.doi.org/10.1016/S0043-1354(96)00373-9

Audebert, M.; Zeman, F.; Beaudoin, R.; Péry, A.; Cravedi, J.-P. Comparative potency approach, based on $\mathrm{H} 2 \mathrm{AX}$ assay for estimating the genotoxicity of polycyclic aromatic hydrocarbons, Toxicol. Appl. Pharmacol., 260, 58-64 (2012). http://dx.doi.org/10.1016/i.taap.2012.01.022 
Bandala, E.R.; Velasco, Y.; Torres, L.G. Decontamination of soil washing wastewater, using solar driven advanced oxidation processes, J. Hazard. Mat., 160, 402-407,(2008).

http://dx.doi.org/10.1016/i.jhazmat.2008.03.011

Beltrán, F. J.; González, M.; Alvarez, P. Tratamiento de águas mediante osidación avanzada (II): Procesos com peróxido de hidrogeno, Ingenieria Química, 332, 165-169 (1997).

Chen, D.; Ray, A.K. Photodegradation kinetics of 4-nitrophenol in $\mathrm{TiO}_{2}$ suspension. Water Res., 32, No. 11, 3223-3234 (2001).

http://dx.doi.org/10.1016/S0043-1354(98)00118-3

Da Rocha, O.R.S.; Dantas, R.F.; Duarte, M.M.M.B.; Duarte, M.M.L.; Silva, V.L. Oil sludge treatment by photocatalysis applying black and white light, Chem. Eng. J., 157, 80-85 (2010). http://dx.doi.org/10.1016/i.cej.2009.10.050

Dantas, R.F.; Rossiter, O.; Teixeira, A.K.R.; Simões, A.S.M.; Silva, V.L. Direct UV photolysis of propranolol and metronidazole in aqueous solution, Chem. Eng. J., $158143-147$ (2010). http://dx.doi.org/10.1016/i.cej.2009.12.017

Embrapa, Manual de métodos de análise de solo, Centro Nacional de Pesquisa de Solos, $2^{\text {nd }}$ ed., Rio de Janeiro (1997).

Esplugas, S.; Giménez, J.; Contreras, S.; Pascual, E.; Rodríguez, M. Comparison of different advanced oxidation processes for phenol degradation, Water Res., 36, 1034-1042 (2002).

http://dx.doi.org/10.1016/S0043-1354(01)00301-3

Faria, P.M.; Rosa, H.V. Hidrocarbonetos policíclicos aromáticos (HPAs): uma revisão de seus aspectos toxicológicos, Rev. Bras. Toxicol., 17, No. 2, 61-70 (2004).

Fernàndez-Alba, A.R.; Hernando, D.; Aguera, A.; Cáceres, J.; Malato, S. Toxicity assays: a way for evaluating AOPs efficiency, Water Res., 36, 42554262 (2002).

http://dx.doi.org/10.1016/S0043-1354(02)00165-3

Ferrarese, E.; Andreottola, G.; Oprea, I.A. Remediation of PAH-contaminated sediments by chemical oxidation, J. Hazard. Mater., 152, 128139 (2008).

http://dx.doi.org/10.1016/i.jhazmat.2007.06.080
Hamed, J.; Acar, Y.B.; Gale, R.J. Pb(II) removal from kaolinite by electrokinetics, J. Geotec. Eng. Div., ASCE, 117, 241-271, (1991).

Higarashi, M.M.; Moreira, J.C.; Oliveira, A.S.; Ferreira, L.V. A utilização de processos oxidativos avançados na descontaminação do meio ambiente, Química - Boletim SPQ. Lisboa. 79, 16-20 (2000).

Jiang, H.; Wang, X.; Wei, A.; Zheng, S.; Liu, F.; Ji, C. A study on the mechanism of harmless and resourceful treatment of oil sludge with microwave, Adv. Mat. Res., 356-360, 1831-1834 (2012).

http://dx.doi.org/10.4028/www.scientific.net/AMR.356$\underline{360.1831}$

Khamehchiyan, M.; Charkhabi, A. H.; Tajik, M. Effects of crude oil contamination on geotechnical properties of clayey and sandy soils, Eng. Geol., 89, 220-229 (2007).

http://dx.doi.org/10.1016/i.enggeo.2006.10.009

Kibble, A.; Harrison, R. Point sources of air pollution, Occup. Med. (Lond.), 55, 425-431 (2005). http://dx.doi.org/10.1093/occmed/kqi138

Lenore, S.C.; Arnold, E.G.; Andrew, D.E. Standard Methods for the Examination of Water and Wastewater, $20^{\text {th }}$ ed., APHA, AWWA and WEF, New York (1998).

Liu, J.; Jiang, X.; Zhou, L.; Han, X.; Cui, Z. Pyrolysis treatment of oil sludge and model-free kinetics analysis, J. Hazard. Mat., 161, No.(2-3), 1208-1215 (2009).

Martins, C.C.; Mahiques, M.M.; Bícego, M.C.; Fukumoto, M.M.; Montone, R.C. Comparison between anthropogenic hydrocarbons and magnetic susceptibility in sediment cores from the Santos Estuary, Brazil, Mar.Pollut. Bull., 54, No. 2, 240-246 (2007).

http://dx.doi.org/10.1016/j.marpolbul.2006.11.006

Mater, L.; Rosa, E.V.C.; Berto, J.; Correa, A.X.R.; Schwingel, P.R.; Radetski, C.M. A simple methodology to evaluate influence of $\mathrm{H}_{2} \mathrm{O}_{2}$ and $\mathrm{Fe}^{2+}$ concentrations on the mineralization and biodegradability of organic compounds in water and soil contaminated with crude petroleum, J. Hazard. Mat., 149, 379-386 (2007).

http://dx.doi.org/10.1016/i.jhazmat.2007.04.005 
Muneer, M., Philip, R., Das, S., Photocatalytic degradation of waste water pollutants. Titanium dioxide-mediated oxidation of a textile dye, acid blue 40, Res. Chem. Intermed., 23, 233-246 (1997). http://dx.doi.org/10.1163/156856797X00448

Ndjou'ou, A.-C., Cassidy, D., Surfactant production accompanying the modified Fenton oxidation of hydrocarbons in soil, Chemosphere, 65, 610-1615 (2006).

Percherancier, J.P., Chapelon, R., Pouyet, B., Semiconductor-sensitized photodegradation of pesticides in water: The case of carbetamide, J. Photochem. and Photobiol. A: Chem., 87, 261-266 (1995).

http://dx.doi.org/10.1016/1010-6030(94)03993-5

Pereira Netto, A.D.; Moreira, J.C.; Dias, A.E.X.; Arbilla, G.; Ferreira, L.F.V.; Oliveira, A.S.; Barek, J. Avaliação da contaminação humana por hidrocarbonetos policíclicos aromáticos (HPAs) e seus derivados nitratos (NHPAs): uma revisão metodológica, Quim. Nova, 23, No. 6, 765-773 (2000).

http://dx.doi.org/10.1590/S0100-40422000000600010

Pignatello, J.J.; Xing, B. Mechanism of slow sorption of organic chemicals to natural particles, Environ. Sci. and Technol., 30, 1-11 (1996). http://dx.doi.org/10.1021/es940683g

Reynaud, S.; Deschaux, P. The effects of polycyclic aromatic hydrocarbons on the immune system of fish: A review, Aquat. Toxic., 77, 229-238 (2006).

http://dx.doi.org/10.1016/i.aquatox.2005.10.018

Shie, J.-L.; Lin, J.-P.; Chang, C.-Y.; Wu, C.-H.; Lee, D.-J.; Chang, C.-F.; Chen, Y.-H. Oxidative thermal treatment of oil sludge at low heating rates, Energy and Fuels, 18, No. 5, 1272-1281 (2004). http://dx.doi.org/10.1021/ef0301811
Sirguey, C.; Silva, P.T.S.; Schwartza, C.; Simonnot, M.-O. Impact of chemical oxidation on soil quality, Chemosphere, 72, No. 2, 282-289 (2008).

http://dx.doi.org/10.1016/i.chemosphere.2008.01.027

Sokolov, V.P.; Chikunova, L.A.; Kudrin, V.B.; Gustov, V.A. Treatment and utilization of oil sludge from flotation treatment of refinery wastewater, Chem. and Technol. Fuels and Oils, 15(3-4), 295298 (1979). http://dx.doi.org/10.1007/BF00721746

Tang, J.; Wang, M.; Wang, F.; Sun, Q.; Zhou, Q. Eco-toxicity of petroleum hydrocarbon contaminated soil, J. Environ. Sci., 23, No. 5, 845851 (2011). http://dx.doi.org/10.1016/S1001$\underline{0742(10) 60517-7}$

Tarantini, A. ; Maîtreb, A. ; Lefèbvre, E. ; Marques, M. ; Rajhi, A.; Douki, T. Polycyclic aromatic hydrocarbons in binary mixtures modulate the efficiency of benzo[a]pyrene to form DNA adducts in human cells, Toxicol., 279 36-44 (2011). http://dx.doi.org/10.1016/j.tox.2010.09.002

USEPA - United States Environmental Protection Agency. Method 3545, Pressurised Fluid Extraction. Test method for evaluating solid waste, $3^{\text {rd }}$ ed, Update III, EPA SW-846.US GPO, Washington, DC (1995).

Yang, S.Y.N.; Connel, D.W.; Hawker, D.W.; Kayal, S.I. Polycyclic aromatic hydrocarbons in air, soil and vegetation in the vicinity of an urban roadway, Sci. Tot. Environ., 102, 229-240 (1991). http://dx.doi.org/10.1016/0048-9697(91)90317-8 